\title{
DISSERTAÇÕES
}

\section{A atuação do movimento sindical junto ao Fórum Nacional do Trabalho}

\author{
Haroldo Pereira Fernandes Filho
}

Curso: Mestrado em Sociologia

Data da defesa: 29 de abril de 2008

Orientador: Prof. Dr. Luís Augusto Sarmento Cavalcanti de Gusmão

\section{Resumo}

Esta pesquisa tem como objetivo descrever a atuação do Movimento Sindical de Trabalhadores e de Empregadores no Fórum Nacional do Trabalho, espaço de negociação política criado em 2003, logo no começo do primeiro mandato do governo do presidente Lula, para tratar das discussões referentes às Reformas Sindical e Trabalhista. Por meio da análise de documentos elaborados pelos próprios atores envolvidos, além dos que refletiam o debate legislativo e partidário sobre o assunto, foi possível mapear os posicionamentos políticos manifestados sobre o debate travado no âmbito daquele espaço. A partir da análise desse conjunto de documentos oficiais e não oficiais, foi explicitada a correlação de forças interna e externa entre as bancadas sindicais de trabalhadores e empregadores ali representadas, além do papel assumido pelo governo em todo esse processo. Concluiu-se que, em que pesem terem fracassado as rodadas de negociação empreendidas pelo governo nesse espaço, a organização sindical brasileira sofreu impactos significativos a partir daquela experiência. Imaginava-se que, por meio do debate entre 
os atores sociais ligados ao mundo do trabalho e da construção de consensos entre eles, fosse possível facilitar a aprovação da proposta de Reforma Sindical no Congresso Nacional, já que esta estaria respaldada pelos próprios interessados. Sendo o consenso uma meta a ser seguida, o Fórum Nacional do Trabalho mostrou-se um espaço de poucos entendimentos entre os representantes dos trabalhadores e os dos empresários que dele participaram. Revelaram-se, por fim, os vitoriosos e os derrotados ao cabo da guerra travada entre os atores sociais ali envolvidos, bem como o impacto desse cenário na própria organização sindical brasileira.

Palavras-chave: movimento sindical de trabalhadores; movimento sindical de empregadores; Fórum Nacional do Trabalho; reforma sindical; reforma trabalhista. 